\title{
Persoalan dan Konstruksi Norma Pengaturan Pembatasan Kebebasan Berkumpul Di Indonesia
}

\author{
Mirza Satria Buana, Wahyudi Djafar, dan Ellisa Vikalista \\ Fakultas Hukum, Universitas Lambung Mangkurat Kalimantan Selatan Indonesia \\ Lembaga Studi dan Advokasi Masyarakat (ELSAM) Jakarta Indonesia \\ Fakultas Ilmu Sosial dan Ilmu Politik Universitas Lambung Mangkurat Kalimantan Selatan \\ Indonesia
}

Jln. Brigjen H. Hasan Basri, Kayutangi, Banjarmasin, Kalimantan Selatan Indonesia, 70123

JIn. Siaga II, No 31, RT. 2/RW.5, Pejaten Barat, Pasar Minggu, Jakarta Selatan, Indonesia 12510

Jln. Brigjen H. Hasan Basri, Kayutangi, Banjarmasin, Kalimantan Selatan, Indonesia 70123

mirza.buana@ulm.ac.id; wahyudi@elsam.or.id; ellisavikalista.fisip@ulm.ac.id

Received: 23 Desember 2020; Accepted: 28 Mei 2021; Published: 25 Agustus 2021

DOI: 10.20885/iustum.vol28.iss3.art6

\begin{abstract}
This article analyzes normative issues in various laws and regulations governing the handling of freedom of peaceful assembly. The formulations of the problems analyzed in this article are: first, whether the regulation and limitation of the right to peaceful assembly in Indonesia are in line with international human rights ideals. Second, how are the arrangements and restrictions on the right of assembly from other countries, which can provide constructive input on the norms for regulating and limiting the freedom of peaceful assembly in Indonesia? This article uses normative legal research and a comparative approach to constitutional law, by looking at concepts and practices from other countries. The conclusions of this study are: first, the regulation and restriction of the freedom of peaceful assembly is still far from the ideal of international human rights. There are still ambivalent and discriminatory arrangements. Second, the conclusion from the results of the comparative study found that there are many variants of gathering activities that are not accommodated by Indonesian legislation, such as: sudden gatherings, continuous and scheduled gatherings, and reciprocal gatherings.
\end{abstract}

Key Words:Advance notification procedure; freedom of peaceful assembly; limitation of freedom; proportionality; protection of human rights

\begin{abstract}
Abstrak
Artikel ini menganalisis isu normatif dalam berbagai peraturan perundang-undangan yang mengatur penanganan kebebasan berkumpul secara damai. Adapun rumusan masalah yang dianalisis dalam artikel ini adalah: pertama, apakah pengaturan dan pembatasan hak berkumpul secara damai di Indonesia telah selaras dengan idealitas HAM Internasional. Kedua, bagaimana pengaturan dan pembatasan hak berkumpul dari negara-negara lain, yang dapat memberi masukan konstruktif normanorma pengaturan dan pembatasan kebebasan berkumpul secara damai di Indonesia? Artikel ini menggunakan penelitian hukum normatif dengan menggunakan pendekatan perbandingan hukum tata negara, dengan melihat konsep-konsep dan praktik-praktik dari negara lain. Kesimpulan dari penelitian ini adalah: pertama, pengaturan dan pembatasan atas kebebasan berkumpul secara damai masih jauh dari idealitas HAM Internasional. Masih ada pengaturan yang bersifat ambivalen dan diskriminatif, Kedua, kesimpulan dari hasil studi perbandingan ditemukan banyak varian dari kegiatan berkumpul yang tidak diakomodasi oleh perundang-undangan di Indonesia, semisal: kegiatan berkumpul mendadak, berkumpul terus menerus dan terjadwal, dan berkumpul balasan.
\end{abstract}

Kata-kata Kunci: Kebebasan berkumpul secara damai; prosedur pemberitahuan di muka; pembatasan kebebasan; proporsionalitas; perlindungan hak asasi manusia 


\section{Pendahuluan}

Di dalam cita negara hukum demokratis, negara yang dijalankan oleh organ pemerintahan memiliki tanggung jawab dan kewajiban dalam Hak Asasi Manusia (HAM). Jaminan konstitusional atas hak-hak dasar warga negara tersebut terpatri dalam norma-norma kontitusi, ${ }^{1}$ dan dalam beberapa undangundang organik. ${ }^{2}$ Konstitusi dalam konteks HAM tidak semata berfungsi sebagai instrumen pembatas dan pemisah kewenangan/kekuasaan politik guna menghindari kesewenang-wenangan, tetapi juga sebagai instrumen yang menghormati, menjaga sekaligus menjamin hak dan kebebasan warga negara.

Artikel ini mengelaborasi isu kebebasan berkumpul damai atau freedom of peaceful assembly. Kebebasan berkumpul berkelindan dengan kebebasankebebasan lain semisal kebebasan untuk menyatakan pendapat dan beropini. Dengan kata lain, hak warga negara untuk berkumpul tidak akan termanifestasi tanpa hadirnya pengakuan terhadap kebebasan berpendapat/berekpresi dan beropini, dan begitu juga sebaliknya. ${ }^{3}$

Pada konteks pasca-otoritarian, kebebasan berkumpul, sekaligus berpendapat/berekspresi dan beropini merupakan instrumen demokrasi yang bertujuan untuk mengawasi pemerintah untuk selalu akuntabel dalam bertindak dan mengeluarkan kebijakan-kebijakan publik, kebebasan ini memberi ruang warga negara untuk melakukan kritik konstruktif kepada pemerintah. 4 Secara konseptual-filosofis dipahami bahwa kebebasan-kebebasan tersebut tidak selalu bermakna mutlak, dalam artian harus tunduk pada mekanisme pembatasan (limitation of rights) dan pengurangan (derogation of rights), semisal dalam kegiatan berkumpul harus dilakukan secara damai. ${ }^{5}$

Indonesia telah berbenah dalam aspek penghormatan, perlindungan dan pemenuhan nilai-nilai HAM. Ratifikasi instrumen pengaturan HAM di struktur politik hukum ketatanegaraan merupakan kebijakan yang diambil oleh

\footnotetext{
1 Pasal 28A-J Undang-Undang Dasar (UUD) 1945 Amandemen.

2 Undang-Undang Nomor 39 Tahun 1999 tentang Hak Asasi Manusia (UU HAM). Lihat juga, UndangUndang Nomor 9 Tahun 1998 tentang Kemerdekaan Menyampaikan Pendapat di Muka Umum.

${ }^{3}$ Jerome J. Shestack, 'The Jurisprudence of Human Rights' dalam Theodor Meron (ed), Human Rights in International Law: Legal and Policy Issues, Clarendon Press, Oxford, 1989, hlm. 77.

4 John P. Humphrey, 'Political and Related Rights', dalam Theodor Meron (ed), Human Rights in International Law: Legal and Policy Issues, Clarendon Press, Oxford, 1989, hlm. 172.

${ }^{5}$ Pasal 20 ayat (1) Deklarasi Universal Hak Asasi Manusia (DUHAM).
} 
pemerintah. Indonesia telah memiliki perangkat hukum berupa Undang-Undang Nomor 9 Tahun 1998 tentang Kemerdekaan Menyampaikan Pendapat di Muka Umum. Undang-undang tersebut berisi norma-norma yang terkesan mendukung penyampaian pendapat dan berekspresi. Namun apabila dicermati secara mendalam justru masih banyak kekosongan norma hukum dan inkonsistensi norma dalam undang-undang tersebut, sehingga masih lemah dalam memberi perlindungan hukum.

Koalisi Kebebasan Berserikat (KKB) mencatat sepanjang Juli 2018 sampai dengan Juni 2019 terdapat 133 peristiwa pelanggaran dan/atau pembatasan terhadap hak atas kebebasan berkumpul di Indonesia. Tercatat di bulan September 2018 terjadi 30 peristiwa, Agustus 2018 sejumlah 20 peristiwa dan Juli 2018 sejumlah 13 peristiwa. ${ }^{6}$ Pembatasan terhadap kebebasan berkumpul semakin represif terutama menjelang pelaksanaan Pemilihan Umum (Pemilu) Serentak 2019, dan aktivitas demonstrasi guna merespon revisi Undang-Undang tentang Komisi Pemberantasan Korupsi (KPK), ${ }^{7}$ serta penolakan publik terhadap pengesahan Undang-Undang tentang Cipta Kerja dengan metode omnibus law. Pada konteks dinamika politik negara yang memanas, isu kebebasan berkumpul secara damai seolah berhadap-hadapan dengan kedaulatan negara. Apalagi ketika Indonesia diterpa pandemi Covid-19 pada awal 2020, aspek keamanan negara lebih diutamakan lewat pengaturan pembatasan represif oleh kepolisian. ${ }^{8}$ Melalui kasus-kasus tersebut di atas dapat dicermati bahwa pembatasan atas kebebasan berkumpul dapat dilakukan lewat norma-norma hukum perundangundangan yang terlalu umum dan sumir. Kemudian diperparah dengan tindakan restriksi oleh aparat penegak hukum yang tidak terukur, dan nihilnya mekanisme akuntabilitas negara untuk menilai praktik pembatasan oleh negara. ${ }^{9}$

${ }^{6}$ Riza I Abdali, M. Ananto Setiawan, Miftah Fadhli, Nuresti T Astarina dan Mirza Satria Buana, Laporan Monitoring dan Evaluasi Implementasi Hak atas Kebebasan Berkumpul dan Berorganisasi di Indonesia Tahun 2018-2019, Koalisi Kebebasan Berserikat, 2019, hlm. 1-2.

${ }^{7}$ Ibid., hlm. 3.

8 Maklumat Kepolisian Republik Indonesia Nomor: MAK/2/III/2020 pada 19 Maret 2020 tentang Kepatuhan Terhadap Kebijakan Pemerintah Dalam Penanganan Penyebaran Virus Corona (Covid-19). Lihat, Herlambang Wiratraman, 'Does Indonesian COVID-19 Emergency Law secure Rule of Law and Human Rights,' Journal of Southeast Asian Human Rights, Volume 4 (1), (2020), 306-334. Lihat, Marcus Mietzner, 'Populist Anti-Scientism, Religious Polarisation and Institutionalised Corruption: How Indonesia’s Democratic Decline Shape It COVID-19, Journal of Current Asian Affairs (2020), 1-23.

${ }^{9}$ Riza I Abdali et el, Op. Cit., hlm. 7. 
Berdasar pada deskripsi di atas, pengaturan dan pembatasan kebebasan berkumpul penting untuk kembali dianalisis. Artikel ini berdasar pada informasi dan data awal dari riset Koalisi Kebebasan Berpendapat 2018-2019 yang penulis juga terlibat sebagai salah satu peneliti. Namun artikel ini lebih tajam melakukan analisis ius constituendum dengan menggunakan pendekatan perbandingan hukum, sehingga lebih bersifat preskriptif, dari pada deskriptif seperti riset-riset sebelumnya.

\section{Rumusan Masalah}

Berdasarkan pada latar belakang dan urgensi pengaturan dan pembatasan hak berkumpul tersebut, artikel ini akan menjawab rumusan masalah sebagai berikut: pertama, apakah pengaturan dan pembatasan hak berkumpul secara damai di Indonesia telah selaras dengan instrumen hukum HAM Internasional, terutama Kovenan Hak Sipil dan Politik (ICCPR) yang termanifestasi dalam beberapa putusan-putusan pengadilan HAM Eropa? Kedua, bagaimana pengaturan dan pembatasan hak berkumpul dari negara-negara anggota Konvensi HAM Eropa (European Convention on Human Rights/ECHR)?

\section{Tujuan Penelitian}

Studi ini bertujuan untuk: pertama, menilai secara obyektif pengaturan dan pembatasan dalam hukum positif Indonesia (ius constitutum) terkait pengaturan dan pembatasan hak berkumpul secara damai; kedua, menilai, menimbang dan mengukur kemungkinan transplantasi norma-norma pengaturan dan pembatasan hak berkumpul secara damai dari negara lain ke dalam perundang-undangan di Indonesia. Analisis dilakukan untuk menggambarkan aspek hukum ius constituendum guna melakukan reformasi hukum.

\section{Metode Penelitian}

Penelitian ini tergolong dalam jenis penelitian hukum normatif, menggunakan pendekatan perbandingan hukum (comparative law approach), dengan melihat konsep dan praktik baik (good practices) dari negara-negara lain dalam konteks perhormatan, perlindungan dan pemenuhan hak atas kebebasan berkumpul secara damai. Paradigma penelitian tidak semata berpijak pada aturan 
normatif yang ada, namun menggambarkan lebih jauh kemungkinankemungkinan reformasi hukum. ${ }^{10}$ Penelitian ini menggunakan pendekatan perundang-undangan dan pendekatan konseptual guna melakukan analisis terhadap peraturan perundang-undangan. Bahan hukum yang terkumpul kemudian dianalisis secara kualitatif sebagai dasar dalam penarikan kesimpulan.

Adapun negara-negara yang menjadi obyek perbandingan adalah beberapa negara-negara anggota Konvensi HAM Eropa yang masuk dalam jurisdiksi peradilan HAM Eropa (The European Court of Human Rights/ECtHR), oleh karena itu penelitian ini menggunakan juga pendekatan putusan hakim (case law approach). Putusan-putusan tersebut relevan dalam konteks Indonesia karena beberapa negara-negara yang menjadi terlapor dan tergugat (plaintiff) dalam kasus-kasus pelanggaran kebebasan berkumpul kebanyakan adalah negaranegara eks-komunis yang sistem politiknya masih berlanggam konservatif dan represif, semisal: Rusia, Moldova, Georgia, Belarus, Armenia dan Lithuania, selain itu negara semi-otoritarian seperti Turki juga menjadi obyek perbandingan. Sedangkan praktik baik (good practices) dapat dicermati di Austria dan Inggris.

Karakter politik negara-negara eks-komunis dan semi-otoriter tersebut menjadi tertium comparationis dengan Indonesia yang merupakan negara pascaotoritarian yang masih memiliki struktur dan budaya hukum yang represif. Kriteria perbandingan dalam studi ini adalah terkait bentuk pengaturanpengaturan kebebasan berkumpul di negara-negara obyek perbandingan, dan mekanisme-mekanisme pengaturan pembatasan kebebasan berkumpul yang diberikan oleh putusan-putusan peradilan HAM Eropa.

\section{Hasil Penelitian dan Pembahasan}

\section{Pengaturan dan Pembatasan terhadap Kebebasan Berkumpul di Indonesia}

Lingkup pengaturan negara terhadap hak atas kebebasan berkumpul secara damai telah diatur secara normatif melalui rumusan norma konstitusi dan perundang-undangan. Negara menjamin "kemerdekaan berserikat dan berkumpul, serta mengeluarkan pikiran dengan lisan dan tulisan."11 Konstitusi

${ }^{10}$ Mark van Hoecke, 'Methodology of Comparative Legal Research', Law and Method (2015), 1-35. Lihat juga, Konrad Zweigert dan H Kötz, An Introduction to Comparative Law, Oxford University Press, Oxford, 1998.

11 Pasal 28E ayat (3) Undang-Undang Dasar (UUD) 1945 Amandemen. 
menjamin “... setiap orang berhak untuk memajukan dirinya dalam memperjuangkan haknya secara kolektif untuk membangun masyarakat, bangsa, dan negaranya."12 Selain itu juga ditegaskan bahwa “... setiap orang berhak untuk berkomunikasi dan memperoleh informasi untuk mengembangkan pribadi dan lingkungan sosialnya, serta berhak untuk mencari, memperoleh, memiliki, menyimpan, mengolah, dan menyampaikan informasi ...."13 Lewat deskripsi normatif di atas jelas tergambar bahwa kebebasan berkumpul secara damai termasuk dalam kriteria kebebasan sipil yang bernuansa liberal, di mana negara atau pemerintah harus bersikap pasif terhadap dinamika kebebasan di masyarakat.

Pengaturan dan pembatasan kebebasan berkumpul di Indonesia diatur dalam Undang-Undang Nomor 9 Tahun 1998 tentang Kemerdekaan Menyampaikan Pendapat di Muka Umum (UU Kemerdekaan Menyampaikan Pendapat). Konsep yang digunakan sangat luas, yakni 'Menyampaikan Pendapat di Muka Umum', namun konsep tersebut terklasifikasi secara sempit dalam 4 (empat) bentuk kegiatan saja: demontrasi; rapat umum; pawai; dan mimbar bebas. ${ }^{14}$ Bagian berikut akan menganalisis beberapa persoalan prosedural dalam pelaksanaan kegiatan berkumpul.

\section{Persoalan dalam Prosedur Pemberitahuan sebelum Kegiatan Berkumpul}

UU Kemerdekaan Menyampaikan Pendapat memberi kewenangan kepada kepolisian untuk menerima pemberitahuan secara tertulis (notification) dari pelaksana kegiatan berkumpul, yang disampaikan selambat-lambatnya 3x24 jam (3 hari) sebelum kegiatan berkumpul dilaksanakan. ${ }^{15}$ Norma ini menimbulkan kerancuan karena tidak memiliki kejelasan fungsi dan tujuan, apakah bertujuan sebagai 'pemberitahuan' atau 'perizinan'. Di dalam tafsir tekstual, 'pemberitahuan' atau 'notifikasi' dianggap sebagai kegiatan yang tidak memerlukan persetujuan. Pemberitahuan, dalam definisi hukum adalah " $a$ writing, containing the information required by an agreement to be communicated to any

12 Pasal 28C ayat (2) Undang-Undang Dasar (UUD) 1945 Amandemen.

13 Pasal 28F Undang-Undang Dasar (UUD) 1945 Amandemen.

14 Pasal 9 ayat (1) Undang-Undang Nomor 9 Tahun 1998 mengatur tentang Kemerdekaan Menyampaikan Pendapat di Muka Umum.

${ }_{15}$ Pasal 10 ayat (1), (2) dan (3) Undang-Undang Nomor 9 Tahun 1998 mengatur tentang Kemerdekaan Menyampaikan Pendapat di Muka Umum. 
person..." atau menyampaikan kabar/informasi supaya diketahui. ${ }^{16}$ Namun dalam elaborasi pasal selanjutnya, disebutkan bahwa kepolisian memberi surat tanda terima pemberitahuan, ${ }^{17}$ dan kepolisian dapat memberi sanksi pembubaran kegiatan berkumpul apabila panitia, peserta atau penanggung jawab kegiatan tidak melakukan proses pemberitahuan kepada kepolisian. ${ }^{18}$

Norma tersebut jelas berpotensi menimbulkan diskriminasi terhadap peserta kegiatan berkumpul dengan tidak diterimanya pemberitahuan atau tidak diberikannya surat tanda terima pemberitahuan. Pihak aparat keamanan dalam praktiknya bisa saja tidak bersedia memberikan STTP (Surat Tanda Terima Pemberitahuan) kepada pihak koordinator unjuk rasa. Kepolisian dapat berargumen bahwa kegiatan tersebut melanggar kepentingan publik, argumentasi tersebut terkadang lemah dalam pembuktian, namun tidak ada mekanisme banding/komplain untuk mempertanyakan argumentasi subyektif tersebut. ${ }^{19}$ Bahkan, pihak kepolisian juga dapat membubarkan acara berkumpul, semisal acara diskusi di lingkungan kampus dan demonstrasi dengan alasan tidak memiliki izin keramaian, tidak ada pemberitahuan, hingga mengganggu ketertiban umum.

Konsepsi pemberitahuan di awal (prior notification) seharusnya mensyaratkan bahwa apabila pemberitahuan disampaikan oleh koordinator acara berkumpul tidak ditanggapi oleh aparat kepolisian maka seharusnya acara berkumpul secara damai tersebut tetap boleh dilaksanakan atau tidak dilarang karena alasan klise: belum melakukan pemberitahuan. Konsepsi prosedur pemberitahuan sejatinya tidak menimbulkan kewajiban bagi aparat keamanan untuk memberikan persetujuan, beda halnya dengan konsep perizinan.

Institusi pemerintah dalam perspektif Hukum Administrasi Negara (HAN) harus memastikan bahwa kebijakan-kebijakan rill yang diambil telah memenuhi Asas-Asas Umum Pemerintahan yang Baik (AUPB) guna memastikan kebijakankebijakan strategis tidak melanggar hak-hak konstitusional warga negara. Jelas terlihat bagaimana mekanisme administrasi negara berkorelasi positif dengan

${ }^{16}$ Law Insider, https://www.lawinsider.com/dictionary/notification. diakses 12 Desember 2020.

17 Pasal 13 ayat (1) huruf (a) Undang-Undang Nomor 9 Tahun 1998 mengatur tentang Kemerdekaan Menyampaikan Pendapat di Muka Umum.

18 Pasal 15 Undang-Undang Nomor 9 Tahun 1998 mengatur tentang Kemerdekaan Menyampaikan Pendapat di Muka Umum.

${ }^{19}$ Riza I Abdali et el, Op. Cit., hlm. 12. 
perlindungan HAM warga negara. Mekanisme pemberitahuan di atas, setidaknya melanggar beberapa asas-asas administrasi negara, sebagai berikut: Pertama, asas kepastian hukum terlanggar karena terdapat kekaburan makna antara 'pemberitahuan' dengan 'perizinan', konsep 'pemberitahuan' tidak sesuai dengan konsep pemberitahuan yang seharusnya, alih-alih justru menjadi mekanisme perizinan yang sumir parameter pengujiannya. UN Human Rights Committee menganggap prosedur 'perizinan' berkedok pemberitahuan sebagai ancaman riil terhadap kebebasan berkumpul secara damai. ${ }^{20}$

Kedua, asas kepentingan umum, yang menjadi parameter dalam mekanisme pemberitahuan juga berpotensi disalah tafsirkan, karena abai terhadap prasyarat demokratis dari kepentingan umum itu sendiri, yaitu dilaksanakan dengan cara yang aspiratif, akomodatif, selektif dan tidak diskriminatif. ${ }^{21}$ Ketiga, mekanisme pemberitahuan tidak dilakukan secara terbuka, namun lewat prosedur-prosedur yang rumit, ambivalen dan birokratis sehingga tidak mudah diakses oleh masyarakat luas. Hal tersebut melanggar asas keterbukaan dan berpotensi melanggar asas pelayanan pemerintahan yang baik, sehingga dapat berdampak terhalangnya aspirasi dan aktivitas berkumpul masyarakat.

Argumentasi terakhir berjangkar pada asas kemanfaatan yang mengharuskan pemerintah, sebagai pemangku kewajiban HAM (duty bearer) untuk selalu berorientasi pada pewujudan keseimbangan antara kepentingankepentingan yang saling berkontestasi. Aparat kepolisian dalam konteks mekanisme pemberitahuan seharusnya memperhatikan kepentingan para pihakpihak yang ingin menyampaikan aspirasi politiknya lewat aksi berkumpul secara damai, bukan semata hanya memerhatikan aspek keamanan dan kepentingan pemerintah yang sangat subyektif.

Seharusnya prosedur administratif pemberitahuan dalam praktik negara demokratis memberi kewajiban-kewajiban tambahan kepada aparat keamanan. Pertama, untuk memastikan ratio jumlah personil aparat keamanan proporsional (tidak berlebihan) dan sesuai dengan pengaturan perundang-undangan yang

${ }^{20}$ Rosalyn Higgins, The European Convention on Human Rights, dalam Theodor Meron (ed), Human Rights in International Law: Legal and Policy Issues, Clarendon Press, Oxford, 1989, hlm. 476.

21 Penjelasan Pasal 10 ayat (1) huruf g, Undang-Undang Nomor 30 Tahun 2014 tentang Administrasi Pemerintahan. 
berlaku. Aparat keamanan wajib menyampaikan informasi-informasi penting perihal mekanisme pemberitahuan di awal tersebut. Sesuai asas proporsionalitas, hanya acara berkumpul dengan jumlah peserta yang besar dan yang berpotensi menimbulkan gesekan sosial-kultural di masyarakat saja yang wajib melakukan mekanisme pemberitahuan di awal. ${ }^{22}$

Kedua, pihak aparat keamanan setelah mengetahui informasi penting dalam rencana kegiatan berkumpul dapat melakukan pengecekan terhadap rekam jejak organisasi, individu-individu yang terlibat dalam aksi, situasi dan kondisi sesuai dengan waktu dan tempat pemberitahuan kegiatan. ${ }^{23}$ Ini adalah kebijakan penilaian berbasis resiko (risk assessment). Melalui pemberitahuan di awal aparat keamanan dapat menyiapkan respon-respon antisipatif terhadap kemungkinan tereskalasinya kegiatan berkumpul dalam tindakan kekerasan yang bersifat merusak kenyamanan dan ketentraman publik.

Guna memberi perspektif normatif-komparatif terhadap pengaturan dan pembatasan kebebasan berkumpul di Indonesia, pada bagian berikut akan mengelaborasi perspektif HAM Internasional, beserta aspek-aspek krusialnya.

\section{Pengaturan dan Pembatasan terhadap Kebebasan Berkumpul secara Damai dalam Idealitas HAM Internasional}

Konsep kebebasan berkumpul dalam konsepsi Deklarasi HAM Internasional (DUHAM) juga erat dikaitakan dengan kebebasan berorganisasi. Keduanya dibaca dalam 'satu tarikan nafas' sebagai 'right to freedom of peaceful assembly and association.'24 Namun dalam ICCPR, kedua kebebasan tersebut dianggap sebagai entitas kebebasan yang terpisah, walaupun keduanya dianggap memiliki kelindan yang kuat. ${ }^{25}$ Di dalam perbandingan dengan dinamika kebebasan berkumpul di negara-negara Eropa, konsep 'berkumpul' dapat mencakup

22 Neil Jarman dan Michael Hamilton, 'Protecting Peaceful Protest: The OSCE/ODIHR and Freedom of Peaceful Assembly' Journal of Human Rights Practice 1 (2) 2009, 208-235, 209.

23 Office for Democratic Institutions and Human Rights (OSCE/ODIHR), Venice Commission Guidelines on Freedom of Peaceful Assembly (2007). http://www.osce.org/item/23835.html. hlm. 27.

24 Pasal 20 Deklarasi Universal Hak Asasi Manusia (DUHAM).

25 Pasal 21 dan Pasal 22 Kovenan Hak Sipil dan Politik (ICCPR). Lihat ratifikasi ICCPR dalam UndangUndang Nomor 12 Tahun 2005. Lihat juga John P Humphrey, Op. Cit., hlm. 188. 
konteks yang lebih luas: dapat dilaksanakan di tempat umum maupun tempat pribadi dan kegiatan berkumpul dapat bersifat statis maupun dinamis. ${ }^{26}$

Mahkamah Internasional dan peradilan HAM Eropa telah memberi rekognisi terhadap beberapa kegiatan berkumpul sebagai berikut: demonstrasi dan/atau unjuk rasa, ${ }^{27}$ aksi duduk, ${ }^{28}$ pemogokan, ${ }^{29}$ blokade jalan, ${ }^{30}$ pawai, ${ }^{31}$ perkumpulan di tempat kediaman pribadi, 32 okupasi suatu bangunan, ${ }^{33}$ dan deklarasi sikap politik. ${ }^{34}$ Kegiatan-kegiatan di atas tidaklah bersifat eksklusifpartikular untuk masyarakat Eropa saja, namun juga kerap terjadi di beberapa negara-negara pasca otoritarian semisal Indonesia. Hal tersebut menandakan bahwa regulasi kebebasan berkumpul di Indonesia masih sangat terbatas.

\section{Aspek-Aspek Penting dalam Pembatasan Berkumpul secara Damai}

Pembatasan hak dan kebebasan dalam perspektif HAM Internasional, pertama dijelaskan dalam DUHAM/UDHR sebagai berikut: "... everyone shall be subject only to such limitations as are determined by law solely for the purpose of securing due recognition and respect for the rights and freedoms of others and of meeting the just requirements of morality, public order and the general welfare in a democratic society." 35 Kemudian dalam konteks kebebasan berkumpul, diksi 'damai' sejatinya merupakan prasyarat dan pembatasan akan sejauh mana kebebasan tersebut dapat dilaksanakan. Konsep 'damai' haruslah dapat dipahami sebagai niatan awal yang semata bertujuan untuk berkumpul guna menyampaikan aspirasi politik secara damai.

Niatan awal baik dapat dilihat dari perilaku awal kelompok aksi, apabila individu dan kelompok berkumpul tersebut melaksanakan hak atas

${ }^{26}$ Rosalyn Higgins, Op. Cit., hlm. 500.

${ }^{27}$ Human Rights Committee on Nikolai Alekseev v. Russia Federation, Communication No. 1873/2009, CCPR/C/ 109/D/1873/2009.

${ }^{28}$ Ç̣loglu and others v. Turkey, Judgment Strasbourg, The European Court of Human Rights (ECtHR).

29 Human Rights Committee on Gelina Youbko v. Belarus, Communication No 1903/2009, CCPR/C/110/D/1903/2009. (ECtHR).

${ }^{30}$ Kudrevicius and others v. Lithuania, Judgment Strasbourg, The European Court of Human Rights

${ }^{31}$ Christians against Racism dan Fascism v. United Kingdom, European Commission on Human Rights (EComHR).

32 Emin Huseynov v. Azerbaijan, Judgment Strasbourg, The European Court of Human Rights (ECtHR).

${ }_{33}$ Cissé v. France, Judgment Strasbourg, The European Court of Human Rights (ECtHR).

${ }^{34}$ Oya Ataman v. Turkey, Judgment Strasbourg, The European Court of Human Rights (ECtHR).

35 Pasal 29 Deklarasi Universal Hak Asasi Manusia (DUHAM/UDHR). 
kebebasannya dengan damai dan baik maka mereka berhak atas perlindungan hak politik. Inilah titik awal dari the assembly must be peaceful. ${ }^{36}$ Dengan kata lain, setiap individu dan kelompok dijamin haknya oleh konstitusi negara untuk menikmati kebebasan berkumpul sepanjang pelaksanaan atas kebebasan berkumpul tersebut dilaksanakan dengan cara damai (anti-kekerasan). ${ }^{37}$

Namun artikel ini berargumen bahwa seorang individu tidak hilang hak dan kebebasannya untuk berkumpul secara damai walaupun semisal telah terjadi eskalasi kekerasan sporadik atau tindakan kekerasan lain yang dilakukan oleh orang lain. Perlindungan hukum berlaku selama individu tersebut tetap melakukan kegiatan berkumpul secara damai dalam niat dan perilaku. ${ }^{38}$ Namun perlu diinsyafi bahwa kebebasan berkumpul, sama halnya dengan wujud kebebasan dan hak sipil politik yang tidak bersifat absolut. Pembatasan dan pengurangan hak atas kebebasan bertujuan untuk menentukan batas jangkauan atas hak tersebut, dan tidak dimaksudkan untuk mengurangi hak suatu individu atau kelompok. 39

Limitasi atas hak politik yang berkelindan antara kebebasan berpendapat dan beropini dengan kebebasan berkumpul secara damai dapat dilihat dalam rumusan ICCPR yang telah diadopsi oleh pemerintah Indonesia. Pembatasan harus dilakukan dengan undang-undang dan memang benar-benar diperlukan untuk melindungi kebebasan, hak dan reputasi orang lain dan guna melindungi keamanan nasional, keamanan publik, kesehatan publik dan nilai moralitas. ${ }^{40}$ Selain itu ditambahkan, ekspresi berpendapat tidak boleh berupa propaganda perang dan ujaran kebencian yang menyinggung isu nasional, rasial, keagamaan yang dapat mendorong terjadinya diskriminasi, ketegangan dan kekerasan. ${ }^{41}$

ICCPR mengatur secara spesifik terkait kebebasan berkumpul, dengan memberi pembatasan-pembatasan yang harus benar-benar diperlukan dalam suatu masyarakat yang demokratis, memenuhi kepentingan keamanan nasional

\footnotetext{
36 Pasal 20 ayat (1) Deklarasi Universal Hak Asasi Manusia (DUHAM/UDHR).

${ }_{37}$ Pasal 24 ayat (1) Undang-Undang Nomor 39 Tahun 1999 tentang Hak Asasi Manusia (UU HAM).

38 Ziliberberg v. Moldova, 4 May 2004, Judgment Strasbourg, The European Court of Human Rights.

39 Viktor Mavi, "Limitation of and Derogations for Human Rights in International Human Rights Instruments", Acta Juridica Hungarica 38 (1997), 107-114.

40 Pasal 19 ayat (3) Kovenan Hak Sipil dan Politik (ICCPR).

${ }^{41}$ Pasal 20 ayat (1) dan (2) Kovenan Hak Sipil dan Politik (ICCPR).
} 
dan keselamatan publik dan bertujuan melindungi kesehatan publik, nilai moral dan perlindungan hak-hak dan kebebasan orang lain.42 Pembatasan dapat dilakukan apabila dalam praktiknya kegiatan berkumpul secara damai tereskalasi ke arah huru-hara, tidak dilakukan 'secara damai' lagi, terdapat ancaman, ekspresi kebencian dan hasutan terhadap kebebasan asasi, identitas rasial dan diskriminasi. Persyaratan pembatasan hak dan kebebasan di atas akan di analisis satu persatu, sebagai berikut:

\section{Pembatasan diatur dan disediakan oleh peraturan (Provided by Law)}

Tujuan utama dari syarat pembatasan hak adalah untuk menghindari kemungkinan pembatasan kebebasan berkumpul dengan menggunakan langkahlangkah yang diambil lewat diskresi lembaga pemerintah. Di dalam HAM Internasional, konsep 'hukum' dalam 'prescribed by law' setidaknya dimaknai ke dalam dua pemahaman:43 Pertama, sebagai produk hukum nasional yang dibentuk oleh kuasa parlemen tingkat nasional berupa undang-undang. Undangundang di dalam konteks Indonesia dibentuk secara kolegial antara pemerintah dengan badan legislatif (DPR). ${ }^{44}$ Pembatasan harus dinormakan dalam undangundang karena pembatasan harus memperoleh legitimasi demokrasi dari wakil rakyat yang merupakan pemegang mandat kehendak rakyat. Kedua, 'hukum' juga ditafsirkan sebagai putusan-putusan pengadilan yang memiliki kekuatan hukum tetap dan bersifat erga omnes. Putusan pengadilan dianggap sebagai produk hukum yang sah karena hakim-hakim disumpah untuk menegakkan hukum dan konstitusi, yang mana HAM menjadi salah satu substansi pentingnya.

\section{Pembatasan sangat diperlukan (Necessary)}

Sebagaimana dijelaskan dalam Prinsip-Prinsip Siracusa, kebijakan pembatasan atas kebebasan haruslah sangat diperlukan, yang dirinci dalam beberapa postulat penting berikut: Pertama, pembatasan dimaksudkan untuk menjawab kebutuhan sosial yang mendesak. Kedua, pembatasan dilakukan secara proporsional atau tidak berlebihan, dan dirasa perlu dalam suatu masyarakat

42 Pasal 21 Kovenan Hak Sipil dan Politik (ICCPR).

43 Patrick M. Garry, "Liberty through Limits: The Bill of Rights as Limited Government Provisions", SMU Law Review 62 (4), 1745- 1760, 1746.

44 Putusan Nomor 065/PUU-II/2004 tentang Pengujian Undang-Undang Nomor 26 Tahun 2000 tentang Pengadilan Hak Asasi Manusia. Mahkamah Konstitusi memberi makna konstitutional terhadap 'hukum' adalah 'undang-undang', produk hukum yang dilegislasi oleh badan legislatif dan eksekutif nasional. 
yang demokratis. ${ }^{45}$ Bagian berikut akan menjelaskan satu persatu prasyarat pembatasan-pembatasan dimaksud.

\section{Pembatasan Diperlukan dalam Masyarakat Demokratis}

Permasalahan konseptual yang kerap muncul adalah luasnya konsep 'dalam suatu masyarakat demokrasi', diinsyafi tidaklah mungkin dapat membangun kesamaan perspektif dari 'masyarakat demokrasi.' Tafsir 'karet' dari konsep ini jelas dapat dipakai pemerintah sebagai kepentingan pemegang kekuasaan politik, semisal memberi justifikasi terhadap makna 'ketertiban umum' dan 'keamanan nasional', dua konsep ini sering dipakai sebagai alasan pembenar pembatasan kebebasan. Artikel ini berargumen bahwa konsep 'dalam suatu masyarakat yang demokratis' merupakan batu uji demokrasi bahwa pembatasan-pembatasan yang dilakukan oleh pemerintah tidak boleh menggangu dinamika masyarakat yang demokratis. Salah satu aspek pembentuk 'masyarakat demokratis' adalah penghormatan terhadap nilai-nilai HAM, akuntabilitas pemerintah dan pembagian kekuasaan dalam pemerintah. ${ }^{46}$

Lebih lanjut soal pembatasan yang diperlukan dalam suatu masyarakat demokrasi juga dapat diukur dalam beberapa aspek sebagai berikut: Pertama, pembatasan memerhatikan konten atau isi materi kegiatan perkumpulan. Hal ini apabila isi materi bersifat buruk, semisal materi orasi yang terang benderang mengancam nyawa orang lain, merendahkan martabat dan martabat kaum minoritas atau ras dan golongan tertentu. ${ }^{4}$ Aparat kepolisian dapat melarang dan/atau membubarkan kegiatan berkumpul tersebut karena memiliki potensi ancaman kekerasan yang nyata kepada publik.

Kedua, kebijakan larangan dan/atau pembatasan kebebasan juga harus melihat konteks sosio-kultural masyarakat sekitar. ${ }^{48}$ Aksi berkumpul dapat diberhentikan sementara ketika azan maghrib berkumandang, ini menyangkut aspek waktu dan adab kepantasan. Pembatasan berkumpul juga dapat

45 Paragrap 10 Prinsip-Prinsip Siracusa tentang Ketentuan Pembatasan dan Pengurangan Hak Asasi Manusia (HAM).

${ }^{46}$ Louis Henkin, "International Human Rights in the United States" dalam Theodor Meron (ed), Human Rights in International Law: Legal and Policy Issues, Clarendon Press, Oxford, 1989, hlm. 25.

${ }^{47}$ United Communist Party of Turkey and Others v. Turkey, Judgment Strasbourg, The European Court of Human Rights (ECtHR), Decision No. 133/1996/752/951.

48 Patrick Garry, Op. Cit., hlm. 1711. 
dinegosiasikan waktu dan tempatnya bersama-sama antara aparat keamanan dengan koordinator kegiatan berkumpul. Kelebihan batas waktu berkumpul yang telah ditentukan oleh peraturan dapat dilanjutkan apabila ada jaminan dari panitia atau koordinator kegiatan berkumpul bahwa kegiatan berkumpul tersebut berniat damai, memiliki resiko rendah/kecil dan tidak mengganggu keselamatan dan kepentingan publik. Selain itu, aspek pemilihan lokasi aksi wajib untuk memerhatikan kenyamanan publik.

Ketiga, dalam melakukan kebijakan pembatasan, penelitian perlu dilakukan oleh aparat kepolisian guna menemukan data dan fakta yang jelas bahwa kegiatan berkumpul memiliki resiko besar atau tidak. Ini adalah penilaian berbasis resiko. Ancaman yang dapat muncul dari kegiatan berkumpul haruslah bersifat nyata, dalam artian tidak bersifat hipotesis, ancaman bahaya dapat berdampak luas dan juga tidak dapat ditolerir dalam nalar kemanusian. ${ }^{9}$

\section{Pembatasan Dilakukan secara Proporsional}

Prinsip proporsional bermakna bahwa setiap intervensi atau campur tangan pemerintah dalam kebebasan berkumpul secara damai haruslah memiliki ukuran yang obyektif, sehingga kebijakan pembatasan tidak berlebihan dilaksanakan dalam konteks masyarakat demokratis. ${ }^{50}$ Prinsip ini juga menuntut keseimbangan yang wajar antara masing-masing aktor pemangku kepentingan yang kepentingannya berlawanan dan memastikan bahwa pembatasan dan/atau pelarangan tersebut dapat melayani kepentingan yang lebih luas. Kegiatan berkumpul yang memiliki pelanggaran yang bersifat kecil tidak dapat dibubarkan. ${ }^{51}$

Negara-negara di Eropa terbiasa menggunakan uji proporsional untuk menilai apakah pelarangan dan/atau pembatasan kebebasan politik dianggap proporsional atau tidak. ${ }^{22}$ Setidaknya ada 3 kriteria dari uji proporsional: Pertama, harus ada koneksi yang rasional antar niat dengan tujuan. Kriteria ini dapat dicontohkan dengan penggunaan dari alat, sarana dan prasarana keamanan oleh aparat keamanan yang harus sesuai dan selaras dengan maksud dan tujuan yang

\footnotetext{
${ }^{49}$ Dennis v. United States, 341 US 494 (1951) dalam Louis Henkin, Op. Cit.., hlm. 27.

${ }^{50}$ Viktor Mavi, Op. Cit., hlm. 107.

51 Niels Petersen, “The German Constitutional Court and Legislative Capture", International Journal of Constitutional Law, Volume 12 Issue 3, 2014, 650-669, hlm. 655.

52 Ibid., hlm. 666.
} 
ingin dicapai. Dengan bahasa normatif perundang-undangan, penggunaan mekanisme pengamanan harus disesuaikan dengan tingkat eskalasi ancaman publik. ${ }^{53}$

Kedua, pelarangan dan/atau pembatasan tidak boleh bertentangan dengan kepentingan dan keselamatan publik. Semisal, tindakan keamanan tidak boleh berdampak luas kepada masyarakat sekitar, semisal penggunaan gas air mata dilarang. ${ }^{54}$ Penggunaan gas air mata dilarang oleh HAM Internasional karena berpotensi mengenai semua orang, tidak hanya berdampak pada individu yang diduga kuat melakukan tindakan kekerasan dan keonaran, tetapi juga dapat berdampak pada masyarakat sekitar.

Ketiga, pelanggaran dan pembatasan harus memiliki tujuan yang sah (legitimate aim). ICCPR mendeskripsikan aspek-aspek penting dalam tujuan pembatasan, semisal untuk keselamatan publik dan kesehatan publik; keamanan nasional dan ketertiban umum; moral publik dan mempertimbangkan hak dan kebebasan orang lain. 55

\section{Aspek Keselamatan Publik (Public Safety) dan Kesehatan Publik (Public Health)}

Di dalam konteks negara kesejahteraan, semisal negara-negara di Eropa Barat, orientasi pembatasan hak dan kebebasan lebih difokuskan pada 'keselamatan' (safety) dan 'kesehatan publik' (public health), ketimbang 'keamanan' (security). ${ }^{56}$ Sebaliknya, negara-negara pasca otoritarian, semisal Indonesia, hukum pembatasan kebebasannya lebih menekankan pada aspek keamanan semata. Aspek keselamatan publik bertujuan untuk melindungi individu dan/atau kelompok dari bahaya baik fisik maupun non-fisik, dan kerugian serius atas properti mereka. ${ }^{57}$ Kesehatan publik juga menjadi aspek yang sangat diperhatikan karena mempengaruhi pemenuhan dan penikmatan hak masyarakat secara kolektif. Kebijakan pembatasan idealnya dimaksudkan untuk mencegah penularan wabah, pandemi atau efek senjata biologis/medik. Kepolisian.

53 Peraturan Kepala Kepolisian Nomor 1 Tahun 2009 tentang Penggunaan Kekuatan dalam Tindakan

54 Peraturan Kepala Kepolisian Nomor 16 Tahun 2006 tentang Pedoman Pengendalian Massa.

${ }_{55}$ Pasal 21 Kovenan Hak Sipil dan Politik (ICCPR).

${ }^{56}$ Clovis Morrison, The Developing European Law of Human Rights, Sijthoff, Leiden, 1967, hlm. 3. hlm. 7.

${ }^{57}$ Dinesh Mohan, Safety as Human Rights, The President and Fellows of Harvard College, Harvard, 2003, 
Aspek Keamanan Nasional (National Security) dan Ketertiban Umum (Public Order)

Alasan keamananan nasional untuk melakukan pembatasan dan/atau pelarangan kegiatan berkumpul kerap digunakan untuk menjaga kedaulatan teritorial dan kedaulatan internal/domestik ancaman serangan dan intervensi berbasis kekerasan. Pembatasan dengan alasan keamanan negara dianggap tidak sah, apabila tujuan sesungguhnya atau akibat yang dihasilkan tidak untuk menjaga dan mengayomi kepentingan keamanan nasional, alih-alih justru digunakan untuk melindungi pemerintah dari rasa malu yang diakibatkan oleh pelanggaran pemerintah ini sendiri. Pemerintah tidak boleh menggunakan alasan keamanan nasional untuk menjustifikasi tindakan pembatasan yang serampangan. ${ }^{58}$

Ketertiban umum menurut istilah aslinya: ordre public, memiliki banyak tafsir dan makna. Secara umum, disamakan dengan istilah kebijakan publik negara (public policy) atau dianggap sebagai raison d'etat.59 Lewat alasan ketertiban umum, sebenarnya pembatasan hanya dapat dilakukan bila memang ada situasi atau tindakan yang berpotensi menimbulkan suatu ancaman serius bagi khalayak umum. Kedua alasan tersebut tidak bisa digunakan serampangan untuk melindungi kepentingan politik pemerintah.

\section{Aspek Moral Publik (Public Moral)}

Diksi 'moral' bersifat partikularistik, dalam artian setiap masyarakat memiliki pemaknaan yang beda-beda tentang moral atau suatu nilai normatif yang dianggap baik. Pemerintah harus mampu menunjukkan bahwa pembatasan atas dasar moral publik ini krusial sekaligus esensial guna menjaga dan memelihara nilai-nilai moral di masyarakat. ${ }^{60}$ Pemerintah memiliki wewenang diskresi untuk menafsirkan definisi dan alasan-alasan berdasar moral publik, tetapi diskresi untuk menafsirkan tersebut tidak boleh menyimpang jauh dari niat dan tujuan baik dari ICCPR, terutama yang berkaitan dengan prinsip nondiskriminasi. 61

\footnotetext{
58 Ben Golder dan George Williams, "Balancing National Security and Human Rights: Assessing Legal Response of Common Law Nations to the Threat of Terrorism", Journal of Comparative Policy Analysis: Research and Practice, Volume 8, Issue 1, 2006, 43-62, hlm. 51.

${ }^{59}$ John P Humphrey, Op. Cit., hlm. 181.

${ }^{60}$ Clovis Morrison, Op. Cit., hlm. 71.

${ }^{61}$ Patrick Garry, Op. Cit., hlm. 71.
} 


\section{Pembatasan tidak boleh Bias Kepentingan Mayoritas}

Artikel ini menambah dua persyaratan pembatasan hak dan kebebasan berkumpul secara damai, yang sejatinya berjangkar pada cita filosofis Deklarasi Universal Hak Asasi Manusia (DUHAM), yang mencantumkan perlu pertimbangan akan "... the just requirements of morality", atau keperluan/kebutuhan moral yang adil. Diksi 'adil' bertujuan agar nilai moral tidak disalahgunakan oleh kepentingan/kebutuhan mayoritas semata. Selain itu 'adil' juga berorientasi pada pemenuhan hak dan kebebasan kelompok mayoritas dan rentan. Prinsip HAM berjangkar pada nilai-nilai kemanusian yang tidak berdasar pada aspirasi dan kebutuhan mayoritas semata. Semua orang, terlepas dari statusnya sebagai mayoritas maupun minoritas, adalah manusia yang terlahir bebas, setara, dan bermartabat dalam menjalankan hak dan kebebasannya. ${ }^{62}$

Aparat keamanan dalam memfasilitasi dan menjaga tertib kegiatan berkumpul tidak boleh berpihak pada kepentingan dan aspirasi kelompok mayoritas, yang terkadang dipenuhi stigma buruk kepada minoritas. Aparat keamanan harus menghindari bias mayoritarian semisal dengan menganggap bahwa kegiatan berkumpul oleh kelompok minoritas pasti menggangu 'ketertiban dan kenyamanan umum' karena minoritas yang sedang berkumpul tersebut memiliki persepsi politik/ideologis yang tidak sama atau berbeda dengan pihak pemerintah atau kelompok mayoritas. 'Kepentingan umum' dalam konteks ini tidak sama dengan 'kepentingan mayoritas' ${ }^{63}$

\section{Pembatasan Berperspektif Minoritas dan Rentan}

Sebagai elaborasi dari pembahasan terkait idealitas pembatasan yang tidak boleh dikuasai oleh hegemoni dan perspektif mayoritarian di atas, pembatasan hak dan kebebasan berkumpul menjadi penting untuk memahami perspektif kelompok minoritas dan rentan. Di dalam konsepsi HAM, setidaknya ada 2 kelompok yang perlu mendapatkan perhatian ekstra dan afirmasi oleh negara/pemerintah. Pertama, adalah kelompok minoritas yang secara kuantitas memiliki kekurangan dalam posisi tawar baik secara politik, kultural maupun

62 Pasal 1-2 Deklarasi Universal Hak Asasi Manusia (DUHAM/UDHR)

${ }^{63}$ Bas de Gaay Fortman, 'Minority Rights: A Major Misconception?', Human Rights Quarterly, Volume 33 No 2, 2011, 265-303, hlm. 270. 
ekonomi. Kelompok minoritas dapat terbagi dalam kelompok minoritas ras/etnis, agama/kepercayaan, pilihan politik dan orientasi seksual.

Kelompok kedua adalah kelompok rentan yang baik secara kuantitas maupun kualitas memiliki kekurangan dalam posisi tawar baik secara politik, kultural, ekonomi maupun struktur sosial. Perempuan, anak, buruh termasuk dalam kategorisasi kelompok rentan karena mereka rentan terhadap struktur sosial yang menindas dan diskriminatif. Namun perlu digaris bawahi bahwa pengkategorian di atas bersifat terbuka dalam artian kedua kelompok: minoritas dan rentan dapat saja memiliki kedua kategori di atas.

\section{Ius Constituendum Pengaturan dan Pembatasan terhadap Kegiatan Berkumpul secara Damai}

Berkaca pada praktik-praktik baik (good practices) dari kasus-kasus di negara-negara Eropa Barat dan putusan-putusan Peradilan HAM Eropa, bagian analisis ini memaparkan beberapa jenis kegiatan berkumpul yang belum diakomodasi oleh hukum positif Indonesia.

\section{Kegiatan Berkumpul Mendadak (Spontaneous Assembly)}

Dengan adanya kewajiban pemberitahuan sebelum kegiatan berkumpul jelas menafikan urgensi acara berkumpul mendadak sebagai kegiatan berkumpul dalam dinamika sosiologis-politik guna melawan suatu narasi dan/atau kebijakan politik pemerintahan. Kebijakan atau narasi tersebut memerlukan respon segera dan cepat dari masyarakat sipil. Karena terjadi dalam konteks sosial-politik yang genting dan perlu, maka ekspresi dalam ruang berkumpul tersebut tidak dapat ditunda. Pengecualian, terutama dalam hal proses dan prosedur pemberitahuan, harus diberikan oleh aparat keamanan untuk kegiatan berkumpul mendadak ini, karena pemerintahan yang menjunjung tinggi nilai demokrasi hendaknya menghormati sekaligus memfasilitasi kegiatan berkumpul mendadak tersebut dalam tujuan merawat nilai-nilai masyarakat yang demokratis, selama kegiatan berkumpul dilaksanakan secara damai. ${ }^{64}$

Hak atas kebebasan berkumpul berkelindan dengan cita negara demokrasi. Negara seharusnya memberi keleluasaan kepada masyarakat untuk melaksanakan

${ }^{64}$ Pasal 10 ayat (1) Armenia's Law on Conducting Meetings, Assemblies and Demonstrations, 2008. 
hak konstitusionalnya untuk berkumpul dan bersama-sama mengekspresikan, dan membela kepentingan bersama. ${ }^{65}$ Walaupun kebebasan berkumpul secara damai kerap dilakukan secara berkelompok dan/atau lewat organisasi tertentu, kebebasan berkumpul sejatinya adalah hak individu. Juga perlu diingat bahwa jangkauan dari hak individu juga melingkupi hak-hak minoritas dan rentan, seperti: buruh perempuan, aktivis lingkungan dan golongan marginal.66

\section{Kegiatan Berkumpul secara Terus-Menerus dan Terjadwal (Scheduled Assembly)}

Dengan berjangkar pada idealitas negara demokrasi tersebut, pemerintah Indonesia seharusnya juga dapat memfasilitasi kegiatan berkumpul secara terusmenerus dan terjadwal (scheduled assembly), semisal seperti Aksi Kamisan, yang dilaksanakan setiap hari kamis dan bertempat di depan Istana Negara. Aksi Kamisan diorganisir dan dilaksanakan secara terjadwal oleh korban dan keluarga korban pelanggaran HAM dimasa lalu, kegiatan Aksi Kamisan juga dilakukan di beberapa daerah-daerah lain, tidak hanya di Jakarta.

Aksi berkumpul yang dilaksanakan secara terjadwal haruslah dimaknai sebagai ekspresi kegelisahan politik masyarakat terkait suatu peristiwa dan kebijakan-kebijakan pemerintah yang menggoncang aras kesadaran publik akan nilai-nilai demokrasi dan prinsip negara hukum, yang telah diabaikan oleh negara. ${ }^{67}$ Dalam aksi berkumpul terus-menerus dan terjadwal ini, koordinator aksi seharusnya hanya wajib melaporkan kegiatan sekali saja, seterusnya tidaklah perlu kembali melakukan pemberitahuan. Aparat keamanan hendaknya memastikan bahwa acara berkumpul terlaksana tanpa tindakan diskriminatif serta mengedepankan asas praduga tidak bersalah.

\section{Kegiatan Berkumpul Balasan (Counter Assembly)}

Selain itu, idealitas negara demokrasi juga merayakan perbedaan pendapat bukan malah merepresi perbedaan pendapat. Di dalam konteks kegiatan berkumpul, acap kali juga sering terjadi kegiatan berkumpul balasan yang bertujuan untuk mengekpresikan kegelisahan dan ketidaksetujuan terkait narasi-narasi yang

${ }^{65}$ Rosalyn Higgins, Op. Cit., hlm. 477.

${ }^{66}$ Ibid., hlm. 478.

${ }^{67}$ Myres McDougal, Harold Lasswell dan Lung-chu Chen, Human Rights and World Public Order: The Basic Politicies of an International Law of Human Dignity, Oxford University Press, Oxford, 1980, hlm.171. 
ditransmisi oleh aksi-aksi demonstrasi yang sedang atau telah dilakukan sebelumnya. Kasus di Austria menunjukkan idealitas pengaturan kegiatan berkumpul balasan.68 Kepolisian sebagai instrumen negara harus memiliki pemahaman hak sipil dan politik bahwa masing-masing kelompok memiliki hak konstitusional untuk menyampaikan ekspresi dan narasi ideologis maupun politis mereka. Kedua kegiatan berkumpul, baik pro maupun kontra haruslah difasilitasi oleh pemerintah guna memastikan bahwa pesan-pesan ideologis maupun politis oleh kedua atau lebih kelompok tersebut terekspresikan dengan damai.

Karena bersifat ideologis-politik, sama halnya dengan aksi berkumpul mendadak, terus-menerus dan terjadwal di atas, aksi berkumpul balasan juga sudah sepatutnya diberi pengecualian dari mekanisme pemberitahuan di muka. Aparat keamanan memiliki kewajiban untuk menjaga dinamika antara kedua kelompok selama masih dalam koridor yang damai: selama tidak tereskalasi pada kekerasan fisik. Aparat kepolisian haruslah menjaga dinamika kedua kelompok tanpa perlu dibubarkan (kecuali apabila aksi sudah tidak damai). Dengan aparat keamanan memberi fasilitas dan menjaga aksi tetap damai, maka pemerintah telah menjalankan kewajibannya dalam HAM dan wujud penghormatan atas kondisi dinamis masyarakat yang demokratis.

\section{Penutup}

Penelitian ini memberi kesimpulan, sebagai berikut: pertama, pengaturan dan pembatasan atas kebebasan berkumpul secara damai masih jauh dari idealitas HAM Internasional. Dalam peraturan perundang-undangan terkait kebebasan berkumpul, masih ada pengaturan yang bersifat ambivalen dan diskriminatif, semisal pengaturan tentang prosedur pemberitahuan yang sebenarnya adalah prosedur perizinan. Pengaturan pemberitahuan ini kontradiksi antara niat dan tujuan dari pembatasan kebebasan berkumpul. Dalam konteks pembatasan atas hak dan kebebasan berkumpul secara damai. Diksi 'damai' adalah batasan konseptual terhadap setiap kegiatan berkumpul. Pemerintah harus memahami dengan benar dan komprehensif syarat-syarat

${ }^{68}$ Arzte fur das Leben v. Austria, Judgment Strasbourg, The European Court of Human Rights (ECtHR) dalam Rosalyn Higgins, Op. Cit., hlm. 480. 
pembatasan yang sah menurut hukum dan HAM. Dibutuhkan uji kebutuhan dan proporsionalitas dalam menilai setiap pembatasan yang dilakukan negara.

Kedua, banyak varian dari kegiatan berkumpul yang tidak diakomodir oleh perundang-undangan, semisal: kegiatan berkumpul mendadak, berkumpul terus menerus dan terjadwal, dan berkumpul balasan. Kegiatan berkumpul secara damai dengan segala variannya merupakan ekspresi masyarakat yang demokratis, sehingga sudah sepatutnya diakomodir oleh pemerintah. Berkaca pada pengalaman negara-negara yang konsisten terhadap prinsip HAM Internasional, aspek 'keselamatan publik' seharusnya lebih diperhatikan ketimbang kepentingan subyektif-politik dari 'keamanan nasional'. Pertimbangan 'moral publik' juga harus dilihat dalam perspektif 'masyarakat yang demokratis', agar pembatasan hak dan kebebasan tidak bias kepentingan mayoritas. Sepatutnya, pelaksanaan hak dan kebebasan berkumpul secara damai mempertimbangkan perspektif dan aspirasi politik kelompok minoritas dan rentan.

\section{Daftar Pustaka}

\section{Buku}

Abdali, Riza I M. Ananto Setiawan, Miftah Fadhli, Nuresti T Astarina dan Mirza Satria Buana, Laporan Monitoring dan Evaluasi Implementasi Hak atas Kebebasan Berkumpul dan Berorganisasi di Indonesia Tahun 2018-2019, Koalisi Kebebasan Berserikat, 2019.

Guidelines on Freedom of Peaceful Assembly, ODIHR, 2010.

Henkin, Louis, 'International Human Rights in the United States' dalam Theodor Meron (ed), Human Rights in International Law: Legal and Policy Issues, Clarendon Press, Oxford, 1989.

Higgins, Rosalyn, The European Convention on Human Rights, dalam Theodor Meron (ed), Human Rights in International Law: Legal and Policy Issues, Clarendon Press, Oxford, 1989.

Humphrey, John P, 'Political and Related Rights', dalam Theodor Meron (ed), Human Rights in International Law: Legal and Policy Issues, Clarendon Press, Oxford, 1989.

McBride, Jeremy, 'Freedom of Association', dalam Hodder Arnold, The Essentials of Human Rights, London, 2005.

McDougal, Myres, Harold Lasswell dan Lung-chu Chen, Human Rights and World Public Order: The Basic Policies of an International Law of Human Dignity, Oxford University Press, Oxford, 1980. 
Morrison, Clovis, The Developing European Law of Human Rights, Sijthoff, Leiden, 1967.

Shestack, Jerome J, 'The Jurisprudence of Human Rights' dalam Theodor Meron (ed), Human Rights in International Law: Legal and Policy Issues, Clarendon Press, Oxford, 1989.

Zweigert, Konrad dan H Kötz, An Introduction to Comparative Law, Oxford University Press, Oxford, 1998.

\section{Jurnal dan Artikel}

Fortman, Bas de Gaay, 'Minority Rights: A Major Misconception?', Human Rights Quarterly, Volume 33 No 2, 2011, 265-303.

Golder, Ben dan George Williams, 'Balancing National Security and Human Rights: Assessing Legal Response of Common Law Nations to the Threat of Terrorism.' Journal of Comparative Policy Analysis: Research and Practice, Volume 8, Issue 1, 2006, 43-62.

Hoecke, Mark van, 'Methodology of Comparative Legal Research', Law and Method (2015).

Jarman, Neil dan Michael Hamilton, 'Protecting Peaceful Protest: The OSCE/ODIHR and Freedom of Peaceful Assembly' Journal of Human Rights Practice 1 (2) 2009, 208-235, 209.

Mietzner, Marcus, 'Populist Anti-Scientism, Religious Polarisation and Institutionalised Corruption: How Indonesia's Democratic Decline Shape It COVID-19, Journal of Current Asian Affairs (2020), 1-23.

Mohan, Dinesh, 'Safety as Human Rights', Harvard, The President and Fellows of Harvard College, 2003.

Petersen, Niels, 'The German Constitutional Court and Legislative Capture', International Journal of Constitutional Law, Volume 12 Issue 3, 2014, 650-669.

Wiratraman, Herlambang, 'Does Indonesian COVID-19 Emergency Law secure Rule of Law and Human Rights,' Journal of Southeast Asian Human Rights, Volume 4 (1), (2020), 306-334.

\section{Putusan Peradilan Nasional dan Internasional}

Arzte fur das Leben v. Austria, 21 June 1988, Judgment Strasbourg, The European Court of Human Rights.

Christians against Racism dan Fascism v. United Kingdom, European Commission on Human Rights.

Cịloglu and others v. Turkey, Judgment Strasbourg, The European Court of Human Rights.

Cissé v. France, Judgment Strasbourg, The European Court of Human Rights.

Dennis v. United States, 341 US 494 (1951)

Emin Huseynov v. Azerbaijan, Judgment Strasbourg, The European Court of Human Rights. 
Human Rights Committee on Gelina Youbko v. Belarus, Communication No 1903/2009, CCPR/C/110/D/1903/2009.

Human Rights Committee on Nikolai Alekseev v. Russia Federation, Communication No. 1873/2009, CCPR/C/ 109/D/1873/2009.

Kudrevicius and others v. Lithuania, Judgment Strasbourg, The European Court of Human Rights.

Oya Ataman v. Turkey, Judgment Strasbourg, The European Court of Human Rights.

Putusan Mahkamah Konstitusi Nomor 065/PUU-II/2004 tentang Pengujian Undang-undang Nomor 26 Tahun 2000 tentang Pengadilan Hak Asasi Manusia.

Shmushkovych v. Ukraine, Judgment Strasbourg, The European Court of Human Rights.

UN Human Rights Council, Joint report of the Special Rapporteur on the rights to freedom of peaceful assembly and of association and the Special Rapporteur on extrajudicial, summary or arbitrary executions on the proper management of assemblies, UN Doc. A/HRC/31/66, 4 February 2016, para. 9.

United Communist Party of Turkey and Others v. Turkey, Judgment Strasbourg, The European Court of Human Rights, Decision No. 133/1996/752/951, para. 47.

Ziliberberg v. Moldova, 4 May 2004, Judgment Strasbourg, The European Court of Human Rights.

\section{Peraturan Perundang-undangan}

Armenia's Law on Conducting Meetings, Assemblies, Rallies and Demonstrations, 2008.

Deklarasi Universal Hak Asasi Manusia (DUHAM).

Undang-Undang Dasar Negara Republik Indonesia Tahun 1945

Undang-Undang Nomor 8 Tahun 1981 tentang Kitab Undang-Undang Hukum Acara Pidana, Lembaran Negara RI Tahun 1981 No. 76, Tambahan Lembaran Negara RI No. 3209.

Undang-Undang Nomor 9 Tahun 1998 tentang Kemerdekaan Menyampaikan Pendapat di Muka Umum, Lembaran Negara RI Tahun 1998 No. 181, Tambahan Lembaran Negara RI No. 3789.

Undang-Undang Nomor 39 Tahun 1999 tentang Hak Asasi Manusia (UU HAM), Lembaran Negara RI Tahun 1999 No. 165, Tambahan Lembaran Negara RI No. 3886. 
Undang-Undang Nomor 12 Tahun 2005 tentang Ratifikasi Kovenan Hak Sipil dan Politik, Lembaran Negara RI Tahun 2005 No. 119, Tambahan Lembaran Negara RI No. 4558.

Undang-Undang Nomor 30 Tahun 2014 tentang Administrasi Pemerintahan, Lembaran Negara RI Tahun 2014 No. 292, Tambahan Lembaran Negara RI No. 5601.

Maklumat Kepolisian Republik Indonesia Nomor: MAK/2/III/2020 pada tanggal 19 Maret 2020 tentang Kepatuhan Terhadap Kebijakan Pemerintah Dalam Penanganan Penyebaran Virus Corona (Covid-19).

Peraturan Kepala Kepolisian Negara Republik Indonesia Nomor 7 Tahun 2012 tentang Tata Cara Penyelenggaraan Pelayanan, Pengamanan dan Penanganan Perkara Penyampaian Pendapat di Muka Umum.

Peraturan Kepala Kepolisian Negara Republik Indonesia Nomor 9 Tahun 2008 tentang Tata Cara Penyelenggaraan Pelayanan, Pengamanan dan Penanganan Perkara Penyampaian Pendapat di Muka Umum.

Peraturan Kepala Kepolisian Nomor 1 Tahun 2009 tentang Penggunaan Kekuatan dalam Tindakan Kepolisian.

Peraturan Kepala Kepolisian Nomor 16 Tahun 2006 tentang Pedoman Pengendalian Massa.

Peraturan Kepala Kepolisian Nomor 8 Tahun 2009 tentang Implementasi Prinsip HAM.

Prinsip-Prinsip Siracusa terhadap Pembatasan Hak dan Kebebasan.

Surat Telegram Nomor STR/364/VI/OPS.2./2020 tentang Perintah Kepada Jajaran Mengenai pencabutan Maklumat Kapolri dan Upaya Mendukung Kebijakan Adaptasi Baru.

\section{Website}

Law Insider, https://www.lawinsider.com/dictionary/notification.

Office for Democratic Institutions and Human Rights (OSCE/ODIHR), Venice Commission Guidelines on Freedom of Peaceful Assembly (2007). http:/ / www.osce.org/item/23835.html. 